\title{
Developing Archaeological Pedagogies in Higher Education: Addressing changes in the Community of Practice of archaeology.
}

Fiona J. L. Handley, Senior Lecturer in Learning and Teaching, University of Brighton. F.handley@brighton.ac.uk

\begin{abstract}
This paper considers how the pedagogy of archaeological teaching in higher education should respond to the changing employment profile of archaeology and the heritage sector. It uses Wenger's model of Communities of Practice (CoP) to explore changes in the archaeological CoP and to generate ideas about new archaeological pedagogies.
\end{abstract}

CoP is a model of learning that is particularly useful for vocational subjects where learning focuses on creating new members through legitimizing peripheral participation. This model is based on social learning and the transformation of identity, and is especially relevant to understanding archaeological teaching with its distinctive pedagogic activities such as fieldwork that bridge the professional/novice divide.

This paper proposes that archaeology teaching prepares students for a variety of different and dynamic engagements within and outside the CoP in response to fewer full-time permanent career opportunities, for example temporary employment, re-training, and campaigning, with the aim of ensuring the CoP's sustainability. This involves developing a range of sophisticated pedagogic solutions that move beyond transferable skills, which develop the strengths of current archaeological pedagogy.

\section{KEYWORDS}

Archaeology; Communities of Practice; curriculum development; employability; heritage; pedagogy; situated learning.

\section{INTRODUCTION}

The context to this paper is the continuing depressed employment situation within the archaeology and heritage sectors, and the discussions that are taking place about how to address this. Employment opportunities for archaeology graduates continue to fall as the sector struggles in the aftermath of the global recession that started in 2007/8; the estimated number of professional archaeologists in 2012-13 was 4,792, a 30\% decrease on that of $2007-8^{1}$. The decline in demand for archaeologists has been compounded by a contraction in the heritage sector more widely, affecting heritage professionals working for bodies such as English Heritage ${ }^{2}$, Arts Council England ${ }^{3}$, local authorities ${ }^{4}$, and the museums sector $^{5} 6$. This turmoil in both the private and public sectors is having a major impact on morale within the remaining workforce, with people being required to do more with fewer resources $^{78}$. Even before the recession part-time and contract working was the norm within archaeology ${ }^{10}$ and it is expected that this situation will continue and become increasingly dominant in the heritage sector more widely ${ }^{12}$. Over the medium to long term this will impact on the sector's skills base and its ability to regenerate when job opportunities begin to increase. The recession has also engendered a period of selfreflection as questions are raised about how the sector has not made a convincing case for 
ongoing support at national and local levels, thus compromising its long term sustainability ${ }^{13}$ 1415

How should archaeology programmes in higher education respond to this situation? Universities do not necessarily need to respond to issues in graduate employability (for example see the debate on teaching archaeological skills to university students ${ }^{16}{ }^{17}$ ) but this issue is wider than just employment opportunities for graduates. Even archaeology programmes that are not targeted at the needs of field archaeology cannot ignore the current crisis. The wider context of how heritage and archaeology are valued must be a key concern to all who teach and research in archaeology, not least because of the impact on student recruitment and the knock-on effect of this on employment in university archaeology departments. Given the increasing need for archaeology departments to justify their existence, one scenario for archaeology in higher education would be for archaeology programmes to become (or for more to become) another liberal arts degree, emphasising generic and transferable skills, with archaeology as the content to engage students. This paper takes a more positive stance. It suggests that the unpredictable outlook for archaeologists and other heritage professions, the inevitable cycle of unemployment and skills shortages associated with the expansion and contraction of the sector, and the need for a greater public awareness of the importance of heritage offers opportunities for developing new archaeological pedagogies, based on reflection and dialogue in authentic learning environments. A useful way of conceptualizing these changes and the pedagogic responses to them is through using Etienne Wenger's Communities of Practice to examine learning and work in archaeology.

\section{COMMUNITIES OF PRACTICE}

Wenger's concept of Community's of Practice $(\mathrm{COP})^{18}$ is a model for understanding how communities, particularly workplace communities, create a shared identity through learning. It is based on the work of psychologist Vygotsky who emphasised the importance of social interaction in learning, especially the role of more knowledgeable others in the 'zone of proximal development' ${ }^{19}$. The model initially focused on how apprentices became full participants in a working community, particularly through informal methods of learning through emersion in the working environment ${ }^{20}$ and was expanded in Wenger's 1998 publication $^{21}$.

Members of a CoP have a shared sense of being part of a community, an understanding of its purpose, and a body of common practices, experiences, stories, and communication techniques. Wenger expresses this as the community having 'a mutual engagement, a joint enterprise, and a shared repertoire ${ }^{\prime 22}$. The way knowledge and understanding is shared and thus meaning created defines the CoP, and Wenger describes a community as being defined by its 'shared histories of learning' ${ }^{23}$. Learning in this scenario is therefore a process of transformation of identity rather than solely the acquisition of knowledge.

Wenger distinguishes two ways that people negotiate meaning when learning, through 'participation' which is the involvement in the social experience of working, and through engagement with the 'reified objects' such as the work processes, sets of rules, or technological knowledge that shape experiences ${ }^{24}$. It is through the entwinement of both participation and reification that meanings are negotiated, with the strengths of one 
compensating for the weaknesses of the other. So the looseness of participation balances the less flexible meanings of reified objects, which conversely clarify and record the more fluid understandings developed in participation.

Lave and Wenger propose that newcomers become full members of a community through 'legitimized peripheral participation' ${ }^{25}$, whereby newcomers are granted enough legitimacy to be treated as potential members. This usually takes place in low risk situations that provide an approximation of full participation. While becoming competent in dealing with reified objects plays a role in transforming newcomers, it is participation that Lave and Wenger emphasise as being the more important. Thus the most important learning sometimes takes place when people are not aware that they are learning.

CoP approaches have been criticised for not paying enough attention to power relations ${ }^{26}$, to the contested nature of knowledge ${ }^{27}$, and to definitions of community ${ }^{28}$, partly as a result of Wenger's later work focusing on management rather than learning ${ }^{29}$. However the strength of the early writings make it a useful starting point for structuring an understanding of archaeology's CoP. As these criticisms suggest there is no absolute definition of an archaeology CoP, but it is defined here as people working in archaeology in the UK, the practice being to create archaeological knowledge through fieldwork, data analysis and synthesis. The limits of the model mean that CoP is useful for analyzing movement through the community, though has less to contribute on issues of power relations, the negotiation of meaning, or how the CoP relates to other CoPs.

\section{Legitimate Peripheral Participation}

With $93 \%$ of professional archaeologists holding a Bachelors degree or higher ${ }^{30}$, archaeology degrees play a key role in legitimizing peripheral participation in archaeology whereby newcomers learn how to become archaeologists through acquiring a particular set of knowledge, behaviors and skills. Fieldwork experience is an essential part of this archaeological training $^{31}$ through creating members of the archaeological community ${ }^{32}$.

Currently most employment pathways within the archaeology community are characterised by movement towards the peripheries as people move out of full time employment, or out of the CoP altogether through unemployment, while in the future there will be more movement in, out and across the CoP as people work temporarily outside archaeology, then gain re-employment in the CoP, etc. People will be continuously adapting to new working environments, and will have to gain and re-gain both reified and participatory skills and knowledge. The edges of the archaeological CoP are blurred by increasing numbers of volunteers who do unpaid work in archaeology e.g. on community digs ${ }^{33} 34$. This boundary area is where some connections to the CoP can be maintained (e.g. former members) or strengthened (e.g. as a route into HE and the CoP), see figure 1. 


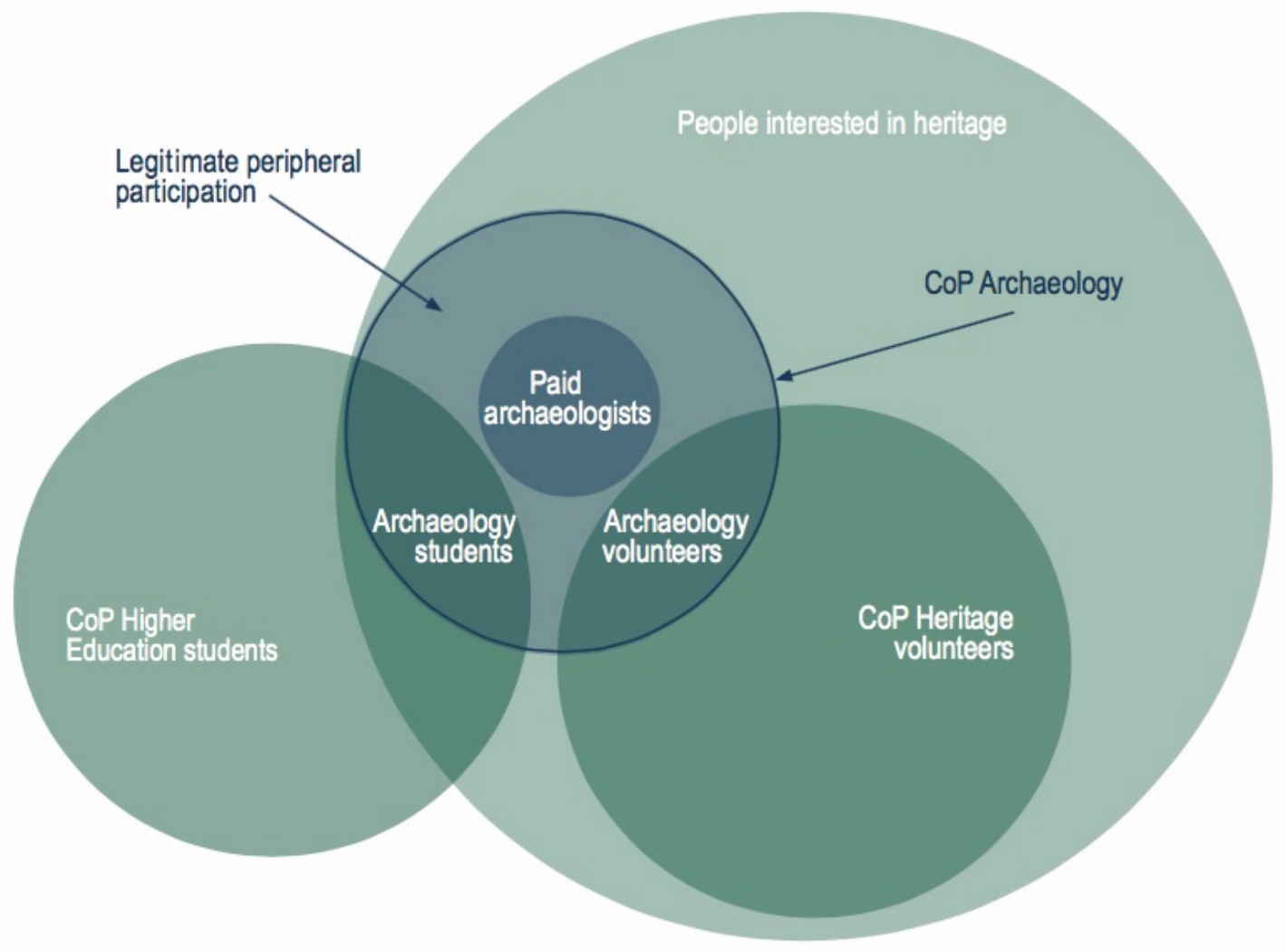

Figure 1

The archaeological Community of Practice and its relationship to other Communities of Practice

Outside of this area is the group of people who are interested in the historic environment. This stakeholder group supports the historic environment financially and is the sector's advocate in the wider world. During the recent period of self-reflection within the discipline attention has turned to influencing volunteers and this group of people to become active campaigners for the historic environment ${ }^{35}{ }^{36}$. While they do not belong to the CoP this external group could have a key role in its long-term stability and sustainability.

The archaeology CoP is therefore characterised by movement and blurred boundaries, and a spectrum of practice from full-time professional career archaeologists in units and universities to volunteer occasional workers on digs. Learning takes place in a variety of ways for example on the job, in low stakes situations such as community digs and training excavations, and in class-based university courses. Learning is through gaining reified skills and knowledge such as finds processing techniques, and especially through participation ${ }^{37}$, which develops the social skills that allows meanings to be made and negotiated.

\section{DEVELOPING EDUCATIONAL APPROACHES}

How can archaeological pedagogies respond to this evolving situation? Lave and Wenger emphasise that legitimate peripheral participation is a viewpoint on learning, not a pedagogical strategy, and that it serves to draw 'attention to key aspects of learning 
experience that may be overlooked ${ }^{38}$. The pedagogies that have developed from the CoP approach emphasise authentic learning environments that offer low risk versions of actual practice ${ }^{39}$ where habits and values as well as formal knowledge can be gained These include real and virtual environments such as problem-based learning scenarios, role-plays, and immersive digital environments ${ }^{40}$.

CoP's emphasis on most learning taking place outside formal learning structures offers a liberating vision of an environment where there is no traditional teaching, only learning. With less emphasis on formal learning activities, more is placed on students reflecting on and articulating their own learning. However there is a tension between the social learning advocated by Lave and Wenger, and the individual learning that reflection involves ${ }^{41} 42$, still this is less problematic where reflection is part of professional practice ${ }^{43}$.

What could this mean for archaeology? The key authentic learning environment in archaeology is fieldwork, and various aspects of its distinctive pedagogy have been investigated e.g. team work $^{44}$, self-reflection ${ }^{45}{ }^{46}$, and participation in the archaeological community ${ }^{47}$, while papers in Burke and Smith $^{48}$ attempt to bring elements of the active learning involved in fieldwork into classroom situations. The following defines a framework for advancing these ideas and developing new pedagogic approaches.

\section{From Transferable to Reflective Skills}

It has already been suggested that there are alternatives to emphasising transferable skills in archaeology programmes as a response to the changes in the sector. In fact, it is a weak option. The focus on transferable skills a way of reframing higher education to serve the skills economy has been criticised ${ }^{49}$, including within archaeology ${ }^{50}$. Wenger's concept of participatory and reified skills offers a further criticism ${ }^{51}{ }^{52}$. Lave and Wenger emphasise participation - the informal knowledge about how to do things - as being key to creating meaning, rather than the technical knowledge of accomplishing certain reified skills. This means that it does not follow that having a skill within one community of practice results in it creating meaning in another. A more important skill is the 'capacity to 'learn how to learn from experience', this is practice in analyzing experience and developing strategies for learning ${ }^{53}$.

The journey archaeology students take as they develop into archaeologists can be the source of this self-reflection, as their identity changes through both formal learning and through participation. Introducing opportunities in teaching for reflection at moments of transition - at the beginning and end of modules or years, after first assessments, at the beginning and end of fieldwork and dissertations - will help students make experiences meaningful to them, help re-present ideas, and reconsider existing ideas ${ }^{54}$. Individual reflection on learning both reified and participation skills (e.g. learning to use a Munsell chart, observing how the language of Munsell colours is used by archaeologists) is therefore a key approach to analyzing experiences and learning how to learn from them. The development of reflective skills supports students' transitions into the archaeology CoP, into other CoPs, but also for entering and re-entering the archaeology CoP to address the continual flux of working within the sector. These abilities will clearly benefit individuals. However they will also benefit the CoP by supporting individual's re-entry into it, allowing people to continue to engage with the sector long enough for their knowledge to be shared 
with new members of the community, and to fill the gaps in middle management that are recognised across both archaeology and heritage 555657 .

While reflection has been recognised as a pedagogic tool relevant to archaeology, there has been little exploration of how it can be used to achieve various learning outcomes, and how to identify different depths in reflective practice ${ }^{58}$. David Schon's identification of knowing-in-action and reflection-in-action ${ }^{60}$ help explain the ways professional practitioners respond to situations where unexpected results appear, or where apparently clear connections need to be reflected upon to make them explicit. Jennifer Moon emphasises the emotional context of reflection, and to achieve higher levels of critical thought, reflection needs to become part of a dialogue ${ }^{61}$, with increasing levels of contextualization within, for example other people's opinions, academic writing, and the wider socio-political context. Supporting this kind of learning requires staff development to better understand how archaeological meaning is created through reflective practice, and to facilitate and assess students reflection.

\section{Preparing for Work Inside and Outside the CoP}

Archaeology programmes should be more explicit about employment profiles in the sector. Disciplines including the visual arts have developed curricula based on enterprise education which recognise their graduates' 'portfolio' careers ${ }^{62}$. Enterprise education prepares students for the realities of self-employment, starting a business, or working for a small or medium-sized enterprise. In archaeology teaching could similarly include activities that both make work patterns in the sector explicit and prepare students for them. One example of the narratives that defines participation in the archaeology CoP is that of the 'digs' worked on, the experience of moving between contracts, who worked where and periods of unemployment ${ }^{63}$. University fieldwork experiences can be a starting point for thinking about identities within archaeology. How and when do archaeologists become conscious of a shared sense of identity? On what values is that identity based, and how do these relate to ethics and responsibilities, at both local and global levels? As Clews notes 'as much as anything else [enterprise education] is about the broad notion of citizenship and civic responsibilities $^{\prime 64}$, and archaeologists need to place their role as practitioners, graduates and individuals within this context.

A more traditional way of students engaging with employment in the discipline is through visits to field units and other heritage institutions, and by attending visiting lectures from their employees. These relationships could be deepened through more shared teaching, research and field activities and broadened to include as wide a variety of practitioners as possible, including people engaged in self-employed, temporary work, or even to people outside the sector but continuing their contact with the discipline in some way with the aim of returning to it. A route beyond this would be a curriculum model whereby undergraduate students learn alongside archaeologists undertaking Continuing Professional Development short courses. This would offer another opportunity for individuals outside the CoP to remain connected to it, cover skills gaps and shortages, and enhance the learning environment for undergraduates. 
Ideas about citizenship, responsibilities and how graduates can make a difference in society cut to the heart of debates about the role of a University education ${ }^{65}$. Broadly speaking these suggest that students' critical thinking skills should be nurtured with the aim of creating socially engaged graduates who understand the implications of their own actions at both local and global levels. Within archaeology teaching, these socially aware critical thinking skills have clustered around subjects such as the role of archaeology in nationalism and identity claims, and indigenous archaeology. There is little in current curricula to encourage students to reflect on how they themselves can make a difference. This is key for the future of the discipline as it cuts to one of the main concerns of current debates which is the role of campaigning ${ }^{66} 67$, in line with other environmental disciplines which build on education to create a 'sense of responsibility for the environment through the development of an environmental ethic and the motivation and skills necessary to participate in environmental improvement ${ }^{68}$. One avenue could be to emphasise individual agency in the key stories of preservation and campaigning. Another would be to foreground case studies that demonstrate archaeology and heritage's potential contribution to society through, for example, community archaeology ${ }^{69} 70$. Preparing graduates to communicate these positive messages about archaeology to influence local and national decision making is new pedagogic territory, and one where further work is needed perhaps through aligning with education for sustainable development ${ }^{71}$.

\section{Pedagogies for the Future of Archaeology}

Learning in and from fieldwork

The approaches described above are broad, but it is also important to consider the learning activities that can support their implementation. The pedagogic strengths of fieldwork suggest that in an ideal learning scenario students should take part in more fieldwork. However with little opportunity for its expansion an alternative is to find ways of making the learning in the rest of the curriculum more like the learning that takes place in fieldwork.

While the learning opportunities in fieldwork are wide ranging, there are certain activities in fieldwork which encourage meta-cognition (i.e. a 'critical awareness of one's own processes of mental functioning ${ }^{72}$ ) that result in a particularly rich learning environment. Karina Croucher et al highlight the importance of students feeling that they are contributing to knowledge creation in some excavations ${ }^{73}$, and this co-creation of knowledge is a key area for higher level cognitive skills to be developed. This is supported in fieldwork training because there are plenty of scenarios that break down the barriers between experts and non-experts, for example when students contribute to low-stakes decision making or have equal skills to tutors in using technology.

Reconstructing these learning scenarios in the classroom could include simulcra e.g. immersive digital environments ${ }^{74}$, situations where students take on the role of researcher e.g. problem-based learning ${ }^{75}$, student-led research projects ${ }^{76}$, and scenarios where students are involved in decisions about course content and structure e.g. co-creation of the curriculum $^{77}$.

Combining these approaches results in scenarios where reflective practice based on fieldwork becomes embedded throughout learning activities, for example: 
Students create an on-line portfolio of evidence drawn from across modules analysing their personal journey to becoming an archaeologist, using their own self-reflection as well as peer and tutor feedback on activities and assessments. The evidence could be drawn on at key reflective moments in their personal development (such as returning after summer breaks and preparing for fieldwork), but also in preparation for assessments that draw from across the curricula such as dissertations.

Restructuring curricula around the identification by students of the knowledge and skills needed to address a task encourages both independent thought and collaboration:

Course teams create a suite of problem-based learning modules, and dedicate each module to answering a single archaeological question such as 'When did humans start behaving symbolically?'. Working in groups students are appropriately supported based on their level and the module learning outcomes, but the emphasis is on students themselves identifying how to address the question, researching, and evaluating how well the information addresses the question.

Exploring new curriculum areas encourages staff and students to work together as coinvestigators, for example:

Staff and students work in consultation with an external organization such as the CBA to create a social media campaign to support an aspect of the heritage environment. Students create, digitise, and curate information to support the initiative, using their varying knowledge of technology to support each other and staff involved. The external organization inputs knowledge on campaigning, and in return gets a range of supporting materials.

\section{CONCLUSION}

The context of this paper is a diminishing sector and a crisis in employment. As a consequence the ideas presented here which focus on exploring participation in archaeology, may seem counter-intuitive. In fact, training peripheral members of the CoP to have more nuanced reflective skills, a keener sense of archaeological values, a personal stake in the future of the historic environment, and better independent and collaborative learning skills, prepares them for lifelong engagement with the CoP. This is equally true whether they go on to be members or leave the CoP but retain an interest in heritage. In this scenario there is no conflict between academic and field archaeology, or between professional and transferable skills, because individuals, the CoP and support for the historic environment all benefit.

The CoP approach has been useful in conceptualizing changes in working practices and as a starting point for thinking what authentic learning environments could be. Importantly, its focus on a community defined by learning suggests that all of those in the CoP are involved in pedagogy whether or not they are 'teaching'. As learners, all members of the CoP, not just students, need to be reflective practitioners, understand values, and think independently and collaboratively. 
This paper identifies a variety of issues that need further discussion. There needs to be a better understanding of archaeological values, and how these relate to public perception of the discipline, the historic environment and how communities engage with the past. There needs to be some exploration of how local, situated and community engagement with heritage relates to the value of understanding the distant past. There needs to an investigation into how archaeology curricula can contribute to the "bold and convincing narrative $^{\prime 78}$ that could help people understand the importance of the historic environment. Most importantly archaeological pedagogies must be recognised as being a key mechanism through which the discipline is created and recreated, not only through formal learning but as an implicit function of the CoP. Developing new pedagogies therefore becomes a key way of changing the sector as a whole.

\footnotetext{
${ }^{1}$ Landward Research Ltd, Archaeology Labour Market Intelligence: Profiling the profession 2012-13 (London, 2013). P.10

${ }^{2}$ English Heritage, 'English Heritage Responds to Revenue Cut', English Heritage 3 July 2013

https://www.english-heritage.org.uk/about/news/revenue-funding/, [accessed 5 September 2014].

${ }^{3}$ Rebecca Atkinson, 'ACE's New Structure Comes into Operation', Museums Journal, 1 June 2013 http://www.museumsassociation.org/museums-journal/news/01062013-ace-new-structure-comes-intooperations, [accessed 5 September 2014].

${ }^{4}$ Mike Pitts, 'Taking Authority for Saving the Past: Who you gonna call?', British Archaeology Issue 122 http://www.archaeologyuk.org/ba/ba122/feat2.shtml, [accessed 5 September 2014].

${ }^{5}$ Creative and Cultural Skills, The Cultural Heritage Blueprint - a workforce development plan for cultural heritage sector in the UK 2012 update (Purfleet, Essex: Creative and Cultural Skills, 2012).

${ }^{6}$ Gina Evans, Cuts Survey 2013 (London: Museums Association, 2013).

${ }^{7}$ Neil Faulkner, 'The Cuts, the Heritage and the People', British Archaeology, November December 2013) (2013): pps 38-39.

${ }^{8}$ Museums Association, Working Wonders: An action plan for the museum workforce (London: Museums Association, 2013).

${ }^{9}$ Prospect Union, Heritage in a Cold Climate (London: Prospect Union, 2014).

${ }^{10}$ Paul Everill, The Invisible Diggers: A Study of British Commercial Archaeology (Oxford: Oxbow Books, 2009).

${ }^{11}$ Karina Croucher, Hannah Cobb, Ange Brennan, Investigating the Role of Fieldwork in Teaching and Learning in Archaeology (Liverpool: Subject Centre for History, Classics and Archaeology, 2008). P.43

${ }^{12}$ Museums Association, Working Wonders: An action plan for the museum workforce (London: Museums Association, 2013).

13 James Larkin, 'Public Archaeology Response to 'The Future Care of Our Nation's Heritage' Debate', Public Archaeology, 12 (3) (2013): pps 200-210.

${ }^{14}$ Prospect Union.

${ }^{15}$ Tim Schadla-Hall, Amara Thornton and Jamie Larkin, 'Editorial', Public Archaeology, 12 (1) (2013): pps 1-6.

${ }^{16}$ Kenneth Aitchison, 'Supply, Demand and a Failure of Understanding: Addressing the Culture Clash between Archaeologists' Expectations for Training and Employment in 'Academia' versus 'Practice", World Archaeology, 36 (2) (2004): pps 203-219.

17 John Collis. Teaching Archaeology in British universities: a personal polemic in Interrogating Pedagogies: Archaeology in Higher Education ed. by Paul Rainbird, Yannis Hamilakiss (Oxford: Archaeopress, 2001), pps. 15-20.
} 
${ }^{18}$ Etienne Wenger, Communities of Practice: Learning, Meaning and Identity (Cambridge: Cambridge University Press, 1998).

${ }^{19}$ L. Vygotsky, Mind in society: the development of the higher psychological processes (Cambridge, MA: Harvard University Press, 1978).

${ }^{20}$ Jean Lave and Etienne Wenger, Situated Learning: Legitimate peripheral participation (Cambridge:

Cambridge University Press, 1991).

${ }^{21}$ Wenger 1998

${ }^{22}$ Wenger 1998 p.152

${ }^{23}$ Ibid p. 93

${ }^{24}$ Ibid.

${ }^{25}$ Lave and Wenger.

${ }^{26}$ Alison Fuller. Critiquing Theories of Learning and Communities of Practice in Communities of Practice: Critical perspectives ed. by Jason Hughes et al.s (London: Routledge, 2007), pps. 17-29.

${ }^{27}$ Mary Lea. 'Communities of Practice' in Higher Education: Useful heuristic or educational model? in Beyond Communities of Practice: Language, power and social context ed. by David Barton, Karin Tustings (Cambridge: Cambridge University Press, 2005), pps. 180-197. P. 185

${ }^{28}$ Nick Jewson. Cultivating Network Analysis: Rethinking the concept of 'community' within 'Communities of Practice' in Communities of Practice: Critical perspectives ed. by Jason Hughes et al.s (London: Routledge, 2007), pps. 68-82.

${ }^{29}$ Etienne Wenger, Richard Mcdermott, William M. Snyder, A Guide to Managing Knowledge: Cultivating Communities of Practice (Boston, MA: Harvard Business School Press, 2002).

${ }^{30}$ Landward Research Ltd P. 12

${ }^{31}$ Quality Assurance Agency, Archaeology Subject Benchmark Statement (Gloucester: Quality Assurance Agency, 2007).

32 Jennifer E. Perry, 'Authentic Learning in Field Schools: Preparing Future Members of the Archaeological Community', World Archaeology, 36 (2) (2004): pps 236-260.

${ }^{33}$ Council for British Archaeology, 'Community Archaeology in the UK: Recent findings' (York: CBA, 2010\}.

${ }^{34}$ Creative and Cultural Skills, The Cultural Heritage Blueprint - a workforce development plan for cultural heritage sector in the UK 2012 update (Purfleet, Essex: Creative and Cultural Skills, 2012).

${ }^{35}$ Louise Ennis, 'Council for British Archaeology Correspondent: Archaeology shrinks while heritage threats continue', British Archaeology, September October 2013) (2013): pps 62-63.

${ }^{36}$ James Larkin, 'Public Archaeology Response to 'The Future Care of Our Nation's Heritage' Debate', Public Archaeology, 12 (3) (2013): pps 200-210. P. 210.

37 Jennifer E. Perry, 'Authentic Learning in Field Schools: Preparing Future Members of the Archaeological Community', World Archaeology, 36 (2) (2004): pps 236-260.

${ }^{38}$ Lave and Wenger p. 41

39 Helen Beetham, Rhona Sharpe. Three (and a Half) Approaches to Understanding How People Learn in Rethinking Pedagogy for a Digital Age: Designing for 21st century learning ed. by Helen Beetham, Rhona Sharpes, 2013), pps. Appendix 1.

${ }^{40}$ Diana Laurillard, Teaching as a Design Science: Building pedagogical patterns for learning and technology (London: Routledge, 2012).

${ }^{41}$ Anne Edwards, 'Let's Get Beyond Community and Practice: the many meanings of learning by participating', The Curriculum Journal, 16 (1) (2005): pps 49-65.

42 Judith Matthews, Philip Candy. New dimensions in the dynamics of learning and knowledge in Understanding Learning at Work ed. by David Boud, John Garricks (London: Routledge, 1999), pps. 47-64.

${ }^{43}$ Donald Schon, Educating the Reflective Practitioner: Toward a new design for teaching and learning in the professions [San Francisco: Jossey-Bass, 1987]

44 Thomas Dowson, Teamwork and Archaeology: A guide to developing team building skills in archaeology students (Liverpool: HEA Subject Centre for History, Classics and Archaeology, nd).

${ }^{45}$ Stuart Brookes, Archaeology in the Field: Enhancing the role of fieldwork training and teaching Research in Archaeological Education, 2008 vol 1, http://www-

new1.heacademy.ac.uk/hca/archaeology/RAEJournal/RAE_all_issues/RAE_Journal_Issue1 [accessed 30 August 2014]

${ }^{46}$ Yannis Hamilakis, 'Archaeology and the politics of pedagogy', World Archaeology, 36 (2) (2004): pps 287309. 
${ }^{47}$ Perry.

${ }^{48}$ Claire Smith, Heather Burke. Lectures as Usual? Teaching Archaeology for Fun in Archaeology to Delight and Instruct: Active learning in the university classroom ed. by Heather Burke, Claire Smiths (Walnut Creek, CA: Left Coast Press, 2007), pps. 11-34.

${ }^{49}$ Stephan Collini, What are Universities for? [London: Penguin, 2012].

${ }^{50}$ Yannis Hamilakis. Interrogating archaeological practice in Interrogating Pedagogies: Archaeology in higher education ed. by Paul Rainbird, Yannis Hamilakiss (Oxford: Archaeopress, 2001), pps. 5-12.

${ }^{51}$ Neville Bennett, Elisabeth Dunne, Clive Carré, Skills Development in Higher Education and Employment (Buckingham: Open University Press, 2000). P. 16

${ }^{52}$ Lea p. 184

${ }^{53}$ Mark Tennant. Is learning transferable? in Understanding Learning at Work ed. by David Boud, John Garricks (London: Routledge, 1999), pps. 165-179. P. 177.

${ }^{54}$ Jennifer Moon, A Handbook of Reflective and Experiential Learning: Theory and practice (London: Routledge Falmer, 2004). P. 87.

${ }^{55}$ Maurice Davies, The Tomorrow People: Entry to the museum workforce (London: Museums Association, 2007).

${ }^{56}$ Landward Research Ltd.

${ }^{57}$ Museums Association, The Cultural Heritage Blueprint - a workforce development plan for cultural heritage in the UK. Museum and gallery update (London: Creative and Cultural Skills, 2012).

${ }^{58}$ Anne Brockbank and lan McGill, Facilitating Reflective Learning in Higher Education (Maidenhead: Open University Press, 2007).

${ }^{59}$ Moon.

${ }^{60}$ Schon.

${ }^{61}$ Brockbank and McGill p. 103.

${ }^{62}$ David Clews, Creating Entrepreneurship: Higher education and the creative industries (Brighton: HEA and NESTA, 2007).

${ }^{63}$ Everill

${ }^{64}$ Clews, p. 12

${ }^{65}$ Collini.

${ }^{66}$ Ennis.

${ }^{67}$ Larkin.

68 Julia Preece, Colin Griffin. Radical and Feminist Pedagogies in The Theory and Practice of Teaching ed. by Peter Jarviss (London: Kogan Page, 2002), pps. 39-54. P. 51.

69 Defence Archaeology Group, 'Project Nightingale', http://www.dmasuk.org, [accessed 15 August 2014].

${ }^{70}$ Rachael Kiddey, John Schofield, 'Digging for (Invisible) People', British Archaeology, July/August 2010 (113) (2010): pps.

${ }^{71}$ Stephen Sterling, The Future Fit Framework: An introductory guide to teaching and learning for sustainability in HE (York: HEA, 2012).

72 Moon p. 216.

${ }^{73}$ Croucher et al.

${ }^{74}$ Clark Aldrich, Learning by Doing: The essential guide to simulations, computer games and pedagogy in elearning and other educational experiences (San Francisco: Jossey-Bass, 2005).

${ }^{75}$ David Boud and Grahame Feletti (eds) The Challenge of Problem Based Learning. Kogan Page (London: Kogan Page, 1991).

${ }^{76}$ Mick Healey, Alan Jenkins, Developing Students as Researchers (York: HEA, 2009).

${ }^{77}$ Catherine Bovill, 'An investigation of co-created curricula within higher education in the UK, Ireland and the USA', Innovations in Education and Teaching International, 51 (1) (2013): pps 15-25.

${ }^{78}$ Larkin p. 210.

\section{BIOGRAPHY}

The author studied archaeology and has worked in a variety of roles in heritage in the UK and abroad. She now works in Learning and Teaching and has interests in curriculum design, assessment, and digital literacies. 
